\title{
KARAKTER MORFOLOGI DAN PERTUMBUHAN SUBSPECIES KAYU MERAH (Pterocarpus indicus Willd.) ASAL PULAU SERAM, MALUKU DAN PULAU FLORES, NUSA TENGGARA TIMUR DI PERSEMAIAN
}

Morphological and growth characters of subspecies kayu merah (Pterocarpus indicus Willd.) from Seram Island, Maluku and Flores Island Nusa Tenggara Timur in the nursery

Vivi Yuskianti ${ }^{1}$, Arianda Poetri Shofia Rochman ${ }^{2}$, Nisa Oktaviani Lingga ${ }^{2}$, dan Budi S. Daryono ${ }^{2}$

${ }^{1}$ Kontributor Utama, Balai Bes ar Penelitian dan Pengembangan Bioteknologi dan Pemuliaan Tanaman Hutan Jl. Palag an Tentara Pelajar KM 15, Purwobinangun, Pakem, Sleman, Yogyakarta, Indonesia email: vivi_yuskianti@yahoo.com

${ }^{2}$ Universitas Gadjah Mada,

Jl. Teknika Selatan, Sinduadi, Mlati Sleman, DI Yogyakarta, Indonesia

Tanggal diterima: 14 Agustus 2018, Tanggal direvisi: 24 Agustus 2018, Disetujui terbit: 30 Juni 2019

\begin{abstract}
Kayu merah (Pterocarpus indicus Willd), a high quality and multiple purpose tree, has been categorized as endangered species. Only a few know that kayu merah has two subspecies (forma) that are differentiated based on the surface structure of the central seed case. This study aims to know the differences on morphological and growth characters of two populations/subspecies kayu merah i.e. Pulau Seram, Mollucas (smooth pods, forma indicus) and Pulau Flores, EastNusa Tenggara (prickly pods, forma echinatus). The genetic relationship of these two populations/subspecies was analyzed using PBSTAT program, while their growth parameter analyzed using SASprogram. The study found differences on morphological and growth characters of kayu merah from Pulau Seram and Pulau Flores. Kayu merah from Pulau Seram has many smooth spots and little grooves on the surface ofits stem and has tapered leaftip shape, whilekayu merah from Pulau Flores has many grooves and little smooth spots, and has splitting leaftip form. The two populations/subspecies were clearly clustered into their own group. Kayu merah from Pulau Seram has better growth than that of Pulau Flores. The result of this research has expected can support conservation andfurther utilization of the species in Indonesia by providing information on preliminary identification of the origin ofkayu merah i.e. Pulau Seramand Pulau Flores as well as early indication of indicus and echinatus subspecies differences in the nursery.
\end{abstract}

Keywords: Pterocarpus indicus, subspecies, origin, Pulau Seram (forma indicus), Pulau Flores (forma echinatus), conservation

\begin{abstract}
ABSTRAK
Kayu merah (Pterocarpus indicus Willd) merupakan jenis pohon bernilai ekonomi ting gi yang mulai mengalami ancaman kepunahan. Sedikit yang mengetahui bahwa terdapat dua subspesies (forma) kayu merah di Indonesia yang dibedakan berdasarkan permukaan kulit buahnya. Penelitian ini bertujuan untuk mengetahui perbedaan karakter morfologi dan pertumbuhan kayu merah as al Pulau Seram (tidak berduri, subspecies indicus) dan Pulau Flores (berduri, subspecies echinatus) padatahap persemaian. Hubungan kekerabatan dan pertumbuhan antara keduanya dianalisis menggunakan program PBSTAT dan SAS. Hasil penelitian menunjukkan perbedaan karakter morfologi pada permukaan batang (banyak totol halus dan sedikit alur di permukaan batang kayu merah as al Pulau Seram dan banyak alur dengan sedikit totol halus di kayu merah as al Pulau Flores), serta bentuk ujung daun (meruncing pada kayu merah asal Pulau Seram dan membelah pada kayu merah as al Pulau Flores). Hasil analisis kekerabatan menunjukkan kedua populasi kayu merah pengelompok berdasarkan populasi/subspeciesnya. Secara umum, kayu merah as al Pulau Seram memiliki pertumbuhan yang lebih baik dibandingkan Pulau Flores. Hasil penelitian ini diharapkan dapat dimanfaatkan sebagai alat identifikasi awal untuk membedakan dua populasi kayu merah yaitu Pulau Seram dan Pulau Flores, serta indikasi awal perbedaan dua subspecies kayu merah (indicus dan echinatus) di persemaian.
\end{abstract}

Kata kunci: Pterocarpus indicus, subs pecies, as al usul, PulauSeram(subs pecies indicus), Pulau Flores (subs pecies echinatus), konservasi

\section{PENDAHULUAN}

Kayu merah (Pterocarpus indicus

Willd.), yang dikenal dengan nama lokal: angsana, sena, sonokembang, narra dan nama dagang: amboyna, Burmese rosew ood, Malay padauk, rosewood, Tenasserim mahogany dan Phillipine mahogany (Orwa, Mutua, Kindt, 
Jamnadass, \& Anthony, 2009) memiliki sebaran alami di Asia Tenggara-Pasifik, mulai dari selatan Burma melalui Asia Tenggara ke Filipina dan pulau-pulau pasifik lainnya (Jøker, 2000). Di Indonesia sendiri, sebaran alami kayu merah berada di seluruh Jawa dan Sulawesi, Maluku, Bali NTB dan NTT, dan Papua (Putri $\&$ Suita, 2005).

Kayu merah mempunyai banyak kegunaan dan bernilai ekonomi tinggi antara lain untuk furnitur, lantai, kabinet dan alat musik; cocok untuk sistem agroforestri dan pohon perindang tanaman kopi dan jenis lainnya (Jøker, 2000). Potensi kayu merah sebagai obatobatan telah diteliti antara lain sebagai anti alergi (Cha et al., 2016), dan pengobatan diabetes (Dharmawan, 2013). Ekstrak kulit batang kayu merah juga terbukti dapat digunakan sebagai pewarna alami kain batik sutera (Lestari \& Satria, 2017). Kayu merah yang banyak ditanam sebagai peneduh di pingir jalan kota dan taman kota juga mempunyai kemampuan dalam menyerap timbal $(\mathrm{Pb})$ dan debu (Inayah, 2010). Lebih lanjut dijelaskan oleh Julianty, Nurzaman, dan Mutaqin (2015) bahwa kayu merah yang ditanam ditaman kota lansia Bandung memiliki kemampuan akumulasi partikulat dan timbal $(\mathrm{Pb})$ menengah sebesar 2,564 ppm dan 0,371 ppm; lebih rendah dibandingkan Fillicium decipiens dan lebih tinggi dibandingkan Swietenia macrophylla.

Kayu merah meskipun sebagai jenis tanaman pioner, tumbuh baik pada kondisi terbuka dengan berbagai jenis tanah pada kisaran 600-1300 m dpl (Jøker, 2000), informasi terbaru menunjukkan bahwa The IUCN Red List of Threatened Species telah mengkategorikan kayu merah sebagai jenis terancam (EN) (IUCN, 2019) . Hal ini karena spesies ini telah punah selama lebih dari 300 tahun di Vietnam, gagal ditemukan di Srilangka serta terancam punah di India, Indonesia dan Filipina (Jøker, 2000).

Kayu merah belum banyak dikenal masyarakat sebagai jenis terancam punah di Indonesia. Hal ini disebabkan karena jenis ini masih relatif mudah ditemukan dalam program rehabilitasi (Hidayatullah, 2008), dan tanaman peneduh pinggir jalan (Inayah, 2010) serta taman kota (Julianty et al., 2015). Sedikit yang mengetahui bahwa kayu merah dibedakan menjadi dua berdasarkan penampakan kulit buahnya; berduri ( $P$. indicus subspecies/forma echinatus) dan tidak berduri $(P$. indicus subspecies/forma indicus) (Jøker, 2000).

Selama ini perbedaan antara kedua subspecies hanya dapat dibedakan berdasarkan kulit buah. Belum ada penelitian yang membandingkan kedua subspecies sejak tahap awal pertumbuhan yaitu tahap persemaian. Penelitian ini akan membandingkan karakter morfologi (batang dan daun) dan karakter pertumbuhan (tinggi dan diameter) dua populasi kayu merah di persemaian. Dua populasi kayu merah yaitu asal Pulau Seram, Maluku dan Pulau Flores, Nusa Tenggara Timur (NTT) digunakan sebagai bahan penelitian. Kedua populasi ini memiliki karakter bentuk buah yang berbeda; Pulau Seram memiliki buah yang tidak berduri (subspecies/forma indicus) sementara Pulau Flores memiliki kulit buah berduri (subspecies/forma echinatus) (Gambar 1) (Orwa et al., 2009).

Penggunaan karakter morfologi daun sebagai alat identifikasi tanaman telah banyak dilakukan. Variasi morfologi daun telah digunakan untuk mengidentifikasi genus Macaranga (Utama, Syamsuardi, \& Arbain, 2012), pengklasifikasian jenis mangga gadung dan mangga madu (Riska, Cahyani, \& Rosadi, 2015), perkembangan morfologi daun untuk mendeteksi dini keragaman morfologi daun hasil persilangan antara mangga varietas Arumanis 143 dengan Podang Urang (Nilasari, Heddy, \& Wardiyati, 2013), dan karakter morfologi hibrid Acacia (Acacia mangium x A. auriculiformis) sejak tingkat semai untuk mendukung keberhasilan perbanyakan vegetatif (Sunarti, 2014).

Hasil penelitian ini diharapkan akan memberikan deskripsi dasar mengenai karakter morfologi dan pertumbuhan bibit kayu merah 
asal Pulau Seram dan Pulau Flores. Selain itu, karena kedua populasi memiliki penampakan kulit buah yang berbeda dan berasal dari dua subspecies yang berbeda, maka penelitian ini juga merupakan tahap awal untuk membedakan karakter morfologi dari dua subspecies kayu merah di Indonesia.

\section{BAHAN DAN METODE}

\section{A. Bahan penelitian}

Bahan yang digunakan adalah bibit kayu merah umur 6 bulan di persemaian. Bibit berasal dari benih hasil eksplorasi dari Pulau Seram, Maluku dan Pulau Flores, Nusa Tenggara Timur (Tabel 1). Jumlah sampel untuk pengamatan karakter morfologi berjumlah 150 bibit ( 2 populasi, 5 pohon induk dan 15 individu untuk setiap pohon induk), sedangkan pengamatan pertumbuhan menggunakan 2 populasi, 4 pohon induk dan 9 individu untuk setiap pohon induk).

\section{B. Metode penelitian}

Pengamatan dilakukan terhadap karakter batang dan daun bibit kayu merah di persemaian, sesuai dengan petunjuk buku Morfologi Tumbuhan (Tjitrosoepomo, 2003). Pengamatan karakter batang dilakukan untuk bentuk batang dan penampakan permukaan batang, sedangkan pengamatan karakter untuk daun meliputi jumlah daun, panjang daun, lebar daun, bentuk daun, bentuk ujung daun, pangkal daun, susunan tulang daun, tepi daun, tesktur daun dan warna daun. Selanjutnya dilakukan pengamatan terhadap karakter pertumbuhan menggunakan parameter tinggi, diameter dan kekokohan semai.

Tabel 1. Informasi pohon induk kayu merah (Pterocarpus indicus) yang digunakan dalam penelitian

\begin{tabular}{|c|c|c|c|c|c|}
\hline Asal & $\begin{array}{l}\text { No } \\
\text { pohon } \\
\text { induk }\end{array}$ & Koordinat & Nama lokasi eksplorasi & $\begin{array}{l}\text { Tipe } \\
\text { buah }\end{array}$ & $\begin{array}{c}\text { Subspecies/ } \\
\text { forma }\end{array}$ \\
\hline \multirow{7}{*}{$\begin{array}{l}\text { Pulau } \\
\text { Seram, } \\
\text { Maluku }\end{array}$} & \multirow[t]{2}{*}{ PS1 } & ${\mathrm{S} 03^{\circ} 18^{\prime} 15^{\prime \prime}}$ & Des a Hatusua, Kecamatan Kairatu, & Tidak & \multirow[t]{2}{*}{ indicus } \\
\hline & & E $128^{\circ} 20^{\prime} 44,0^{\prime \prime}$ & Kabupaten SeramBarat & berduri & \\
\hline & \multirow[t]{2}{*}{ PS7* } & $\mathrm{S} 03^{\circ} 18^{\prime} 18,0^{\prime \prime}$ & Des a Hatusua, Kecamatan Kairatu, & Tidak & \multirow[t]{2}{*}{ indicus } \\
\hline & & E $128^{\circ} 20^{\prime} 54,7^{\prime \prime}$ & Kabupaten Pulau SeramBarat & & \\
\hline & PS9* & $\begin{array}{l}\text { S } 03^{\circ} 18^{\prime} 09^{\prime \prime} \\
\text { E } 128^{\circ} 20^{\prime} 43,9^{\prime \prime}\end{array}$ & $\begin{array}{l}\text { Desa Hatusua, Kecamatan Kairatu, } \\
\text { Kabupaten Pulau SeramBarat }\end{array}$ & $\begin{array}{l}\text { Tidak } \\
\text { berduri }\end{array}$ & indicus \\
\hline & PS13* & $\begin{array}{l}\mathrm{S} 03^{\circ} 18^{\prime} 04,1^{\prime \prime} \\
\text { E } 128^{\circ} 21^{\prime} 0,1^{\prime \prime}\end{array}$ & $\begin{array}{l}\text { Desa Hatusua, Kecamatan Kairatu, } \\
\text { Kabupaten Pulau SeramBarat }\end{array}$ & $\begin{array}{l}\text { Tidak } \\
\text { berduri }\end{array}$ & indicus \\
\hline & PS15* & $\begin{array}{l}\text { S } 03^{\circ} 17^{\prime} 49,3^{\prime \prime} \\
\text { E } 128^{\circ} 21^{\prime} 02,5^{\prime \prime}\end{array}$ & $\begin{array}{l}\text { Des a Aerapa, Kecamatan Kairatu, } \\
\text { Kabupaten Pulau Seram Barat }\end{array}$ & Tidak & indicus \\
\hline \multirow{10}{*}{$\begin{array}{l}\text { Pulau } \\
\text { Flores, } \\
\text { NTT }^{1)}\end{array}$} & \multirow[t]{2}{*}{ PF1 } & S $08^{\circ} 49.579^{\prime}$ & Des a Lekogoko, Kecamatan & \multirow[t]{2}{*}{ Berduri } & \multirow[t]{2}{*}{ echinatus } \\
\hline & & E $120^{\circ} 54.018^{\prime}$ & Aimeree, Kabupaten Ngada & & \\
\hline & \multirow[t]{2}{*}{ PF13* } & S $08^{\circ} 48.386^{\prime}$ & Desa Watungene, Kecamatan Kota & \multirow[t]{2}{*}{ Berduri } & \multirow[t]{2}{*}{ echinatus } \\
\hline & & E $120^{\circ} 46.326^{\prime}$ & $\begin{array}{l}\text { Komba, Kabupaten Manggarai } \\
\text { Timur }\end{array}$ & & \\
\hline & \multirow[t]{2}{*}{ PF15* } & S $08^{\circ} 48.356^{\prime}$ & Desa W atungene, Kecamatan Kota & \multirow[t]{2}{*}{ Berduri } & \multirow[t]{2}{*}{ echinatus } \\
\hline & & E $120^{\circ} 46.326^{\prime}$ & $\begin{array}{l}\text { Komba, Kabupaten Manggarai } \\
\text { Timur }\end{array}$ & & \\
\hline & \multirow[t]{2}{*}{ PF16* } & $\mathrm{S} 08^{\circ} 48.345^{\prime}$ & Desa Watungene, Kecamatan Kota & \multirow[t]{2}{*}{ Berduri } & \multirow[t]{2}{*}{ echinatus } \\
\hline & & E $120^{\circ} 46.336^{\prime}$ & $\begin{array}{l}\text { Komba, Kabupaten Manggarai } \\
\text { Timur }\end{array}$ & & \\
\hline & \multirow[t]{2}{*}{ PF23* } & $\mathrm{S} 08^{\circ} 48.236^{\prime}$ & Desa Watungene, Kecamatan Kota & \multirow[t]{2}{*}{ Berduri } & \multirow[t]{2}{*}{ echinatus } \\
\hline & & E $120^{\circ} 45.862^{\prime}$ & $\begin{array}{l}\text { Komba, Kabupaten Manggarai } \\
\text { Timur }\end{array}$ & & \\
\hline
\end{tabular}

Keterangan: PS $=$ Pulau Seram, $\mathrm{PF}=$ Pulau Flores, $*$ pohon induk untuk pengamatan pertumbuhan Sumber data: ${ }^{1)}$ Yuskianti, Is mail, \& Pamungkas, (2017). 


\section{Analisis data}

Analisis similarity, dan dendogram pada program PBSTAT (Suwarno, Sobir, Aswidinnoor, \& Syukur, 2008) digunakan untuk mengetahui hubungan genetik/ kekerabatan antara kedua populasi/subspecies. Parameter pertumbuhan dianalisis varian (ANOVA) menggunakan program SAS (Statistical Analysis Software) version 9.0.
Apabila terdapat perbedaan signifikan antar pohon induk, maka pengujian dilanjutkan menggunakan uji Duncan. Model matematis yang digunakan adalah:

$$
\mathrm{Y}_{i j}=\mu+\mathrm{P}_{i}+\varepsilon_{i j}
$$

Dimana $: i=1,2, \ldots ., \mathrm{t}$ dan $\mathrm{j}=1,2, \ldots \mathrm{r}$.

$\mathrm{Y}_{i j} \quad=$ Variabel yang diamati/diukur

$\mu \quad=$ Rerata umum

$\mathrm{P}_{i} \quad=$ Pengaruh famili ke-1

$\varepsilon_{i j} \quad=$ Randomerror pada pengamatan

Tabel 2. Hasil pengamatan karakter morfologibibit kayu merah asal Pulau Seram(subspecies indicus) dan Pulau Flores (subspecies echinatus)

\begin{tabular}{lll}
\hline Karakter & Pulau Seram(subspecies indicus) & Pulau Flores (subspecies echinatus) \\
\hline Batang & & \\
Bentuk batang & Bulat & Bulat \\
Permukaan batang & Banyaktotol-totol halus & Banyak alur-alur halus \\
Daun & Jorong & Jorong \\
Bentuk daun & Membulat & Membulat \\
Pangkal daun & Menyirip & Menyirip \\
Susunan tulang daun & Rata & Rata \\
Tepi daun & Halus & Halus \\
Tekstur daun & Hijau muda-hijau-hijau tua & Hijau muda-hijau-hijau tua \\
Warna daun & Meruncing & Membelah \\
Ujung daun & $5-8$ helai daun & $3-8$ helai daun \\
Jumlah daun/tangkai & $3,88-9,82 \mathrm{~cm}$ & $2,47-6,52 \mathrm{~cm}$ \\
Panjang daun (P) & $2,24-6,62 \mathrm{~cm}$ & $1,80-4,53 \mathrm{~cm}$ \\
Lebar daun (L) & $1,36-2,17$ & $1,20-1,90$ \\
Rasio P/Ldaun & & \\
\end{tabular}

\section{HASIL DAN PEMBAHASAN}

Hasil penelitian menunjukkan adanya perbedaan karakter morfologi batang dan daun dari kedua populasi kayu merah di persemaian (Tabel 2 dan Gambar 1). Bentuk batang untuk kedua populasi kayu merah sama yaitu berbentuk bulat (teres), tetapi perbedaan ditemukan pada permukaan batangnya. Bibit kayu merah asal Pulau Seram (forma indicus) memiliki banyak totol-totol halus tanpa/sedikit alur di bagian batangnya sementara kayu merah asal Pulau Flores (forma ehinatus) memiliki banyak alur-alur halus berwarna coklat tua dibagian batangnya dengan lebih sedikit totoltotol halus (Gambar 1).

Daun kayu merah memiliki susunan daun majemuk (folium compositum) dan pada satu tangkai daun terdapat 3-8 helaian daun (Gambar 1). Persamaan ditemukan pada karakter bentuk daun, pangkal daun, susunan tulang daun, tepi daun, tekstur daun dan warna daun. Bentuk daun kedua jenis kayu merah adalah jorong (ovalis atau ellipticus), pangkal daun membulat, susunan tulang daun menyirip, dengan tepi daun yang rata, tekstur halus dan warna daun mulai dari hijau muda-hijau-hijau tua (Gambar 1). Perbedaan ditemukan pada bentuk ujung daun, dengan bentuk ujung daun angsana asal Pulau Seram (forma indicus) memiliki ujung daun yang meruncing, sementara ujung daun kayu merah asal Pulau Flores (forma echinatus) membelah (Gambar 1).

Untuk kayu merah asal Pulau Flores (PF), pohon induk nomor PF15 dan PF16 memiliki hubungan kekerabatan terdekat di antara pohon induk lainnya yang ditunjukkan dengan nilai similarity tertinggi $(0,944)$, sementara hubungan kekerabatan terjauh dimiliki oleh kayu merah asal Pulau Seram (PS1) dan Pulau Flores (PF1) yaitu 0,151 (Tabel 3 ). 


\begin{tabular}{|c|c|c|}
\hline Karakter & $\begin{array}{l}\text { Pulau Seram } \\
\text { (subspecies indicus) }\end{array}$ & $\begin{array}{l}\text { Pulau Flores } \\
\text { (subspecies echinatus) }\end{array}$ \\
\hline Bentuk buah & & \\
\hline Batang & & \\
\hline Susunan daun & & \\
\hline Bentuk daun & & \\
\hline $\begin{array}{l}\text { Bentukujung } \\
\text { daun }\end{array}$ & & \\
\hline $\begin{array}{l}\text { Bentuk } \\
\text { pangkaldaun }\end{array}$ & & \\
\hline
\end{tabular}

Gambar 1. Karakter morfologi kayu merah as al Pulau Seram(subspecies indicus) dan Pulau Flores (subspecies echinatus)

Dendogram menunjukkan bahwa kayu merah asal Pulau Seram (PS) mempunyai klaster yang berbeda dengan kayu merah asal Pulau Flores (PF) (Gambar 2).

PS13 dan PS15 mempunyai hubungan kekerabatan yang paling dekat, disusul dengan PS9 serta PS1 dan PS7 untuk populasi kayu merah asal Pulau Seram, sementara kayu merah
PF15 dan PF16 mempunyai hubungan kekerabatan yang paling dekat di populasi kayu merah Pulau Flores, disusul oleh PF23, PF1 dan terakhir dengan klaster PF13 (Gambar 2). Hasil dendogram berdasarkan data morfologi (Gambar 2) ini sesuai dengan hasil penelitian genetik menggunakan penanda DNA (Sulistyawati \& Widyatmoko, 2017). 
Tabel3. Nilai similarity antar berbagai pohon induk kayu merah as al Pulau Seram (PS) dan Pulau Flores (PF).

\begin{tabular}{lllllllllll}
\hline & PS1 & PS7 & PS9 & PS15 & PS13 & PF1 & PF23 & PF13 & PF15 & PF16 \\
\hline PS1 & - & & & & & & & & & \\
PS7 & 0,869 & - & & & & & & & & \\
PS9 & 0,699 & 0,673 & - & & & & & & & \\
PS15 & 0,866 & 0,839 & 0,833 & - & & & & & & \\
PS13 & 0,749 & 0,722 & 0,813 & 0,883 & - & & & & & \\
PF1 & 0,151 & 0,212 & 0,235 & 0,242 & 0,330 & - & & & & \\
PF23 & 0,189 & 0,162 & 0,345 & 0,323 & 0,440 & 0,875 & - & & & \\
PF13 & 0,251 & 0,224 & 0,522 & 0,385 & 0,502 & 0,712 & 0,823 & - & & \\
PF15 & 0,281 & 0,254 & 0,379 & 0,386 & 0,474 & 0,856 & 0,908 & 0,833 & - & \\
PF16 & 0,322 & 0,310 & 0,406 & 0,413 & 0,501 & 0,829 & 0,852 & 0,837 & 0,944 & - \\
\hline
\end{tabular}

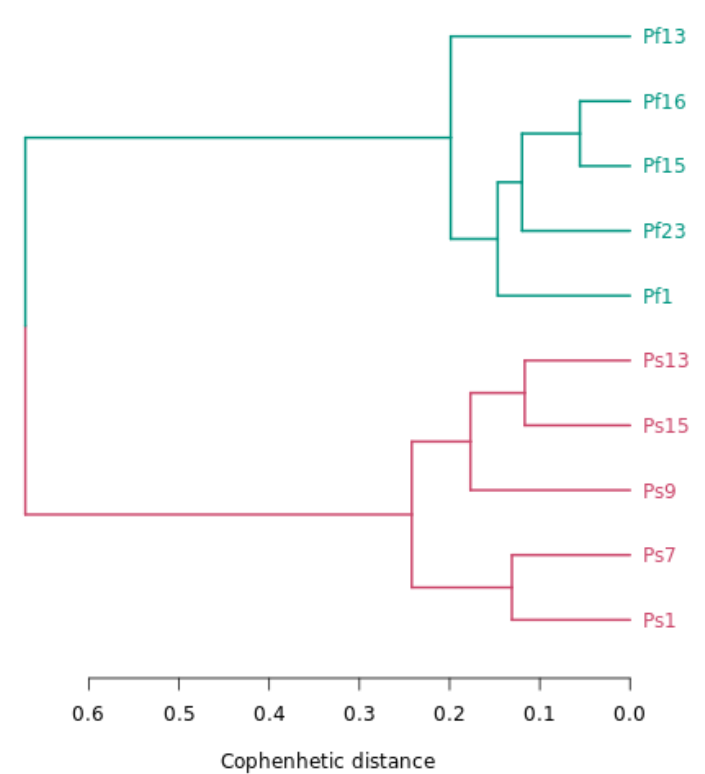

Gambar 2. Dendogram kayu merah asal Pulau Seram (PS) dan Pulau Flores (PF)

Walaupun penelitian DNA bertujuan untuk membedakan populasi, tetapi kedua hasil ini menunjukkan kemungkinan adanya perbedaan tidak hanya antar populasi, tetapi juga kemungkinan perbedaan antar subspecies. Sebelumnya diketahui bahwa kayu merah asal Kupang, Soe, Kefamenamu di NTT, dan Pulau Seram di Maluku merupakan kayu merah subspesies/forma indicus yang tidak memiliki duri pada bagian buahnya (Yuskianti et al., 2015), sementara kayu merah asal Manggarai Timur dan Ngada di Pulau Flores, NTT merupakan subspesies/forma echinatus yang memiliki duri pada bagian buahnya (Yuskianti et al., 2017).

Hasil ANOVA pohon induk untuk ketiga parameter pertumbuhan menunjukkan terdapat perbedaan nyata untuk parameter tinggi dan kekokohan semai, sementara parameter diameter tidak berbeda nyata (Tabel 4).

Hasil uji lanjut Duncan (DMRT) untuk semua karakter pertumbuhan menunjukkan bahwa secara umum kayu merah asal Pulau Seram memiliki pertumbuhan yang lebih baik dibandingkan dengan Pulau Flores (Tabel 5).

Tabel 4. Analis a varian pohon induk kayu merah untuk parameter tinggi, diameter dan kekokohan semai.

\begin{tabular}{|c|c|c|c|c|c|}
\hline Parameter & $\begin{array}{c}\text { Sumber } \\
\text { variasi }\end{array}$ & $\begin{array}{c}\text { Derajat } \\
\text { bebas }\end{array}$ & Jumlah kuadrat & Kuadrat tengah & $\mathrm{F}$ \\
\hline \multirow[t]{3}{*}{ Tinggi } & Pohon induk & 7 & 13303,27 & 1900,47 & $4,47 *$ \\
\hline & Error & 64 & 27220,79 & 425,32 & \\
\hline & Total & 71 & 40524,06 & & \\
\hline \multirow[t]{3}{*}{ Diameter } & Pohon Induk & 7 & 31,51 & 4,50 & $1,28 \mathrm{~ns}$ \\
\hline & Error & 64 & 224,76 & 3,51 & \\
\hline & Total & 71 & 256,26 & & \\
\hline \multirow[t]{3}{*}{ Kekokohan semai } & Pohon Induk & 7 & 104,30 & 14,90 & $5,21 *$ \\
\hline & Error & 64 & 183,08 & 2,86 & \\
\hline & Total & 71 & 287,38 & & \\
\hline
\end{tabular}

Keterangan: $\mathrm{ns}=$ tidak berbeda nyata, $*=$ berbeda nyata pada taraf uji $5 \%$. 
Tabel 5. Hasil uji Duncan terhadap dua kelompok asal pohon induk (Pulau Seram dan Pulau Flores) dan antar pohon induk untuk parameter pertumbuhan bibit kayu merah

\begin{tabular}{llll}
\hline Sumber keragaman & Tinggi & Diameter & Kekokohan semai \\
\hline Asal & & & \\
Pulau Seram & $87,111 \mathrm{a}$ & $8,817 \mathrm{a}$ & $9,932 \mathrm{a}$ \\
Pulau Flores & $69,178 \mathrm{~b}$ & $7,757 \mathrm{~b}$ & $8,859 \mathrm{~b}$ \\
Pohon induk & & & \\
PS 7 & $107,111 \mathrm{a}$ & $9,4256 \mathrm{a}$ & $11,4515 \mathrm{a}$ \\
PS 9 & $64,333 \mathrm{~b}$ & $8,3944 \mathrm{a}$ & $10,2354 \mathrm{abc}$ \\
PS 13 & $71,111 \mathrm{bc}$ & $8,2656 \mathrm{a}$ & $8,5390 \mathrm{~cd}$ \\
PS 15 & $85,889 \mathrm{~b}$ & $9,1822 \mathrm{a}$ & $9,5009 \mathrm{bc}$ \\
PF13 & $71,222 \mathrm{bc}$ & $7,9567 \mathrm{a}$ & $8,7792 \mathrm{bcd}$ \\
PF15 & $77,044 \mathrm{bc}$ & $7,4478 \mathrm{a}$ & $10,3480 \mathrm{ab}$ \\
PF 16 & $69,444 \mathrm{bc}$ & $7,5611 \mathrm{a}$ & $9,0330 \mathrm{bc}$ \\
PF 23 & $89,000 \mathrm{c}$ & $8,0622 \mathrm{a}$ & $7,2757 \mathrm{~d}$ \\
\hline
\end{tabular}

Keterang an: Angka rata-rata deng an huruf yang sama di setiap kolommenunjukkan tidak ada perbedaan nyata pada taraf uji $5 \%$.

Kayu merah asal Pulau Seram (PS7) memiliki tinggi, diameter dan kekokohan semai yang lebih baik dibandingkan kayu merah lainnya, sementara kayu merah Pulau Flores (PF23) menunjukkan rata-rata pertumbuhan yang lebih rendah dibandingkan yang lainnya (Tabel 5).

Penelitian ini menunjukkan adanya perbedaan morfologi pada karakter batang (permukaan batang), daun (bentuk ujung daun) (Gambar 1 dan Tabel 2) dan pertumbuhan bibit kayu merah asal Pulau Seram dan Pulau Flores (Tabel 4 dan 5). Informasi ini dapat digunakan untuk mengidentifikasi asal usul bibit secara cepat melalui pengamatan morfologi pada tahap persemaian. Selain itu, karena kedua populasi berasal dari dua subspecies yang berbeda, maka hasil penelitian ini juga dapat menjadi informasi awal untuk membedakan subspecies kayu merah sejak tahap persemaian tanpa harus menunggu kayu merah mengalami fase generatif dan menghasilkan buah.

Hasil penelitian ini diharapkan dapat mendukung upaya konservasi dan potensi pemanfaatan kayu merah di Indonesia. Informasi morfologi dan pertumbuhan kedua subspecies ini dapat mendukung program rehabilitasi, restorasi khususnya pada lahanlahan hutan lindung karena kedua subspecies ini merupakan jenis pionir dan dapat hidup pada berbagai kondisi lingkungan (Jøker, 2000). Untuk tujuan komersial, kayu merah subspecies indicus seperti asal Pulau Seram diduga telah banyak dimanfaatkan di Indonesia antara lain sebagai tanaman peneduh pinggir jalan dan taman kota. Hal ini didukung oleh fakta bahwa jenis ini mempunyai pertumbuhan yang cepat (Tabel 4 dan 5); tidak mempunyai duri pada bagian buahnya (Gambar 1); serta memiliki kemampuan mengakumulasi partikulat dan timbal (Pb) (Julianty et al., 2015). Jenis ini juga diduga telah digunakan sebagai obat anti alergi (Cha et al., 2016) dan diabetes (Dharmawan, 2013), serta pewarna alami (Lestari \& Satria, 2017).

Karena umumnya tumbuh pada lahanlahan terjal berbukit dan kering, kayu merah subspecies echinatus diduga memiliki tekstur kayu yang kuat dan keras, seperti kayu merah yang ditemui di Pulau Flores, NTT (Yuskianti et al., 2017). Masyarakat adat menggunakannya setidaknya sebagai tiang utama rumah atau bahkan seluruh bagian rumah, bila mampu. Dalam pembuatan sarung parang khas Bajawa Flores, harga sarung parang yang berasal dari kayunya kayu merah memiliki nilai jual paling tinggi dibandingkan sarung dari jenis kayu lainnya (Yuskianti et al., 2017).

Keanekaragaman kayu merah yang ada di Indonesia belum banyak diketahui. Sejauh ini 
tampaknya hanya satu subspecies yang telah banyak ditanam dan dimanfaatkan di Indonesia yaitu subspecies indicus, sementara subspecies echinatus belum banyak diketahui. Dengan diketahuinya adanya 2 subspecies kayu merah di Indonesia, maka diharapkan pemanfaatan kedua jenis tersebut dapat disesuaikan dengan tujuan penggunaan sehingga mengurangi tekanan yang tinggi pada subspecies tertentu. Selain itu, potensi peningkatan keragaman genetik untuk program pemuliaan pohon juga bertambah tinggi dengan mengelola kedua subspecies ini.

Hal lain yang perlu mendapat perhatian adalah bahwa belum adanya penelitian keragaman kayu merah tidak hanya terjadi pada level subspecies tapi juga dalam subspecies. Pengamatan kayu merah asal Pulau Seram (Maluku) menunjukkan adanya variasi jenis kayu merah asal Pulau Seram (subspecies indicus) yaitu gaba-gaba, bic ang kuning, kasturi dan linggua batu (Yuskianti et al., 2015). Penduduk lokal membedakan ke-empat jenis tersebut umumnya berdasarkan warna, kekerasan kayu dan tekstur kayu. Pemanfaatan jenis kayu merah ini juga berbeda, linggua batu paling disukai karena mempunyai tekstur yang paling keras sementara gaba-gaba memiliki tekstur yang lebih lunak (Yuskianti et al., 2015).

Hasil eksplorasi kayu merah di beberapa sebaran alami di Indonesia menunjukkan bahwa penebangan liar, alih fungsi lahan dan terbatasnya regenerasi alami, khususnya pada subspecies echinatus, menjadi ancaman utama bagi keberadaan kayu merah di Indonesia (Yuskianti et al., 2015). Pembangunan dua plot konservasi eks situ kayu merah di KHDTK Gunung Kidul, DI Yogyakarta, dan KHDTK Wonogiri, Jawa Tengah dengan menggunakan materi genetik hasil eksplorasi di 5 sebaran alam di Indonesia, yang juga mencakup kedua subspecies, (Yuskianti et al., 2016), merupakan salah satu cara untuk menyelamatkan jenis tersebut dari ancaman kepunahan. Plot ini tidak hanya menjadi sumber koleksi materi genetik, tetapi juga dapat digunakan untuk mendukung upaya konservasi, program pemuliaan pohon dan kegiatan pemanfaatan kayu merah lainnya di Indonesia.

\section{KESIMPULAN}

Hasil penelitian menunjukkan adanya perbedaan pada karakter morfologi dan pertumbuhan pada dua populasi kayu merah asal Pulau Seram dan Pulau Flores. Permukaan batang bibit kayu merah asal Pulau Seram memiliki banyak totol-totol halus tanpa/sedikit alur di bagian batangnya sementara kayu merah asal Pulau Flores memiliki banyak alur-alur halus berwarna coklat tua di bagian batangnya dengan lebih sedikit totol-totol halus. Bentuk ujung daun kayu merah asal Pulau Seram meruncing, sementara asal Pulau Flores membelah. Hasil analisis hubungan kekerabatan antara kedua populasi/subspecies kayu merah menunjukkan kedua populasi/subspecies mengelompok menjadi dua bagian yaitu Pulau Seram (tidak berduri, subspecies indicus) dan Pulau Flores (berduri, subspecies echinatus). Secara umum, kayu merah asal Pulau Seram memiliki karakter pertumbuhan (tinggi, diameter dan kekokohan semai) yang lebih baik dibandingkan asal Pulau Flores. Hasil penelitian ini diharapkan dapat digunakan sebagai alat identifikasi awal asal usul kayu merah yaitu Pulau Seram dan Pulau Flores. Selain itu karena kedua populasi berasal dari dua subspecies yang berbeda, maka hasil ini dapat menjadi indikasi awal untuk membedakan subspecies indicus dan echinatus kayu merah di Indonesia.

\section{UCAPAN TERIMA KASIH}

Penulis mengucapkan terima kasih kepada Muhamara Yora dari Institut Pertanian Bogor (IPB) atas bantuannya dalam melakukan analisis data program PBSTAT. Penulisan makalah telah mendapat persetujuan dari semua penulis. Setiap penulis berperan dalam mendukung publikasi ini. VY beperan dalam membuat desain penelitian, melakukan analisis data dan menjadi penulis utama makalah; APSR 
berperan dalam melakukan penelitian morfologi batang dan daun kayu merah; NOL berperan melakukan penelitian pertumbuhan kayu merah; dan BSD menjadi pembimbing penelitian.

\section{DAFTAR PUSTAKA}

Cha, H. S., Kim, W. J., Lee, M. H., Kim, S. Y., Kim, S. H., Lee, K. H., \& Kim, T. J. (2016). Inhibitory effect of Pterocarpus indicus Willd water extract on IgE/Ag-induced mast cell and atopic dermatitis-like mouse models. Bioscience, Biotechnology and Biochemistry, 80(5), 911-919. https ://doi.org/10.1080/09168451.2015.1135 044

Dharmawan, F. R. (2013). Pengujian aktivitas hipoglikemik ekstrak air daun angsana Pterocarpus indicus Willd terhadap histopatologi sel hepar tikus diabetes aloksan. Universitas Katolik Widya Mandala Surabaya.

Hidayatullah, M. (2008). Rehabilitasi lahan dan hutan di Nus a Tenggara Timur. Info Hutan, $V(1), 17-24$.

Inayah, S. N. (2010). Studi kandungan Pb dan kadar debu pada daun angsana (Pterocarpus indicus) dan rumpur gajah mini (Axonopus sp) di pusat kota Tangerang. Universitas Islam Negeri Syarif Hidayatullah.

IUCN. (2019). The IUCN Red List of Threatened Species Version 2019-2. https://www.iucnredlist.org, downloaded on 01 Oktober 2019.

Jøker, D. (2000). Pterocarpus indicus Willd. Seed Leaflet Danida Forest Seed Centre No.37 September 2000.

Julianty, N. C., Nurzaman, M., \& Mutaqin, A. Z. (2015). Hubungan karakteristik daun dengan akumulasi partikulat dan timbal $(\mathrm{Pb})$ pada daun pohon Pterocarpus indicus Willd., Swietenia macrophylla King., dan Filicium decipiens (Wight \& Arn) Thwaites di Kawasan Tamna Lansia kota Bandung. Biotika (Jurnal Ilmiah Biologi), 13(2).

Lestari, D. W., \& Satria, Y. (2017). Pemanfaatan kulit kayu angsana (Pterocarpus indicus) sebagai sumber zat warna alam pada pewarnaan kain batik sutera. Dinamika Kerajinan Dan Batik, 34(1), 35-42.

Nilas ari, A. N., Heddy, J. B. S., \& Wardiyati, T. (2013). Identifikasi keragaman morfologi daun mangga (Mangifera indica L.) pada tanaman hasil persilangan antara varietas Arumanis 143 dengan Podang Urang umur 2 tahun. Jurnal Produksi Tanaman, 1(1), 6169. Retrieved from http://protan.studentjournal.ub.ac.id/index.ph $\mathrm{p} / \mathrm{protan} /$ article/view/8

Orwa, C., Mutua, A., Kindt, R., Jamnadass, R., \& Anthony, S. (2009). Agroforestree Database:a tree reference and selection guide version 4.0.

Putri, K. P., \& Suita, E. (2005). Angsana (Pterocarpus indicus Willd). In Atlas Benih Tanaman Hutan Indonesia, Jilid V (Edisi Khusus Andalan Jawa Barat), D. Rohadi, D.F. Djam'an, A. Aminah, dan R. Sitorus (Eds) (Vol. 4, pp. 7-9).

Riska, S. Y., Cahyani, L., \& Rosadi, M. I. (2015). Klasifikasi jenis tanaman mangga gadung dan mangga madu berdasarkan tulang daun. Jurnal Buana Informatika, 6(1), 41-50.

Sulistyawati, P., \& Widyatmoko, A. Y. P. B. C. (2017). Keragaman genetik populasi kayu Merah (Pterocarpus indicus Willd) menggunakan penanda Random Amplified Polymorphism DNA. Jurnal Pemuliaan Tanaman Hutan, 11(1), 67-76.

Sunarti, S. (2014). Karakter morfologi hibrid Acacia (A. mangium $\mathrm{x}$ A. auriculiformis) di persemaian. Jurnal Pemuliaan Tanaman Hutan, 8(2), 69-80.

Suwarno, W.B., Sobir, As widinnoor, H., \& Syukur, M. (2008). PBSTAT: A Web-based statistical analys is software. In The 3rd International Conference on Mathematics and Statistics, Mathermatics and Statistics: bridge for academia, bussiness, and governement in the entrepreneurial era (pp. 852-858).

Tjitrosoepomo, G. (2003). Morfologi tumbuhan (cetakan ke). Yogyakarta: Gadjah Mada University Press.

Utama, A. P., Syamsuardi, \& Arbain, A. (2012). Studi morfometrik daun macaranga Thou. di Hutan Pendidikan dan Penelitian Biologi (HPPB). Jurnal Biologi Universitas Andalas, 1(1), 54-62.

Yuskianti, V., Ismail, B., \& Pamungkas, T. (2017). Sebaran alami kayu merah (Pterocarpus indicus Willd.) di Pulau Flores Nusa Tenggara Timur. In A. Septiasari, A. Astuti, I. N. Berlian, K. Kharismamurti, N. C. Merdekawati, \& Y. R. Alkarim (Eds.), Prosiding Seminar Nasional Biodiversitas Vol. 6 No. 3 (pp. 124-128). Solo: Kelompok Studi Biodiversitas Program Studi Biologi FMIPA UNS. 
Vol. 13 No. 1, Juni 2019, p. 1 - 10

Yuskianti, V., Widyatmoko, A. Y. P. B. C., Yelnititis, Charomaini, M., Ismail, B., Pamungkas, T., ... Triyanta. (2015). Konservasidan bioteknologi untuk jeniskayu kuku, kayu merah dan eboni. Yogyakarta.
Yuskianti, V., Yelnititis, Charomaini, M., Ismail, B., Pamungkas, T., Prastyono, ... Hartono. (2016). Konservasi untuk Jenis Kayu Kuku, Kayu Merah dan Eboni. Yogyakarta. 